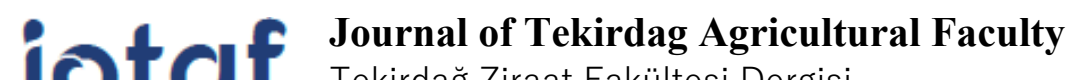 \\ Tekirdağ Ziraat Fakültesi Dergisi
}

\section{The Effects of Feeding Frequencies on The Growth Performance and Life Rate in Electric Yellow Fish Fry (Labidochromis caeruleus)}

\author{
Sarı Prenses Ciklet Yavrularında (Labidochromis caeruleus), Ögün Sayısının Büyüme \\ Performansı ve Yaşama Gücü Üzerine Etkileri
}

\section{Cemal POLAT $^{1 *}$, Çetin YAĞCILAR ${ }^{2}$}

\begin{abstract}
Ornamental fish farming has become an important industry in the world. Ornamental fish are called living gems because of their color, shape and behavior. Modern ornamental fish production requires a nutritionally balanced, cost-effective and sustainable feeding process. Among the operating costs in aquaculture, the cost of feed has a ratio varying between $40 \%$ and $60 \%$ among the total other expenses. In this study, it was aimed to investigate the effects of meal number on growth performance and survival rate in Electric yellow cichlid fries (Labidochromis caeruleus). 60 Electric yellow cichlid fries were stocked in 12 aquariums of $33 * 35 * 40 \mathrm{~cm}$ size established in Tekirdag Namık Kemal University Technical Sciences Vocational School Fisheries Laboratory. The study was carried out in 3 repetitions: 1 meal per day, 3 meals, 5 meals and 1 meal every other day, up to 5\% of body weight, by applying 4 different meals to fish. During the study, weight and height measurements were made every 30 days, and the data obtained were evaluated at the end of the study and the effect of growth on the number of meals was investigated. At the end of the trial, body weights were measured as $3.696 \pm 1.517 \mathrm{~g}, 4.757 \pm 1.898 \mathrm{~g}, 3.786 \pm$ $1.539 \mathrm{~g}$ and $3.380 \pm 1.318 \mathrm{~g}$, and total heights were $5.726 \pm 0.675 \mathrm{~cm}, 6.300 \pm 0.530 \mathrm{~cm}, 5.640 \pm 0.776 \mathrm{~cm}$ and $4.562 \pm 1.952 \mathrm{~cm}$, respectively. No statistical difference was found between the number of meals administered in the study in terms of average body weight gain and specific growth rate. However, according to the results obtained in the length of the fish, a statistical difference was found between feeding 1 meal every other day and the number of other meals. As a result, considering the fish health and feed cost, 3 times daily feeding frequency of the fish was considered sufficient.
\end{abstract}

Keywords: Labidochromis caeruleus, Feeding frequency, Growth performance, Survival rate, Body weight gain

\footnotetext{
1*Sorumlu Yazar/Corresponding Author: Cemal POLAT, Tekirdağ Namık Kemal University Agriculture Faculty, Tekirdağ, TURKEY. E-mail: cpolat@nku.edu.tr (D) OrcID: https://orcid.org/0000-0002-7419-2864

${ }^{2}$ Çetin YAĞCILAR, Tekirdağ Namık Kemal University Veterinary Medicine, Tekirdağ and TURKEY. E-mail: cyagcilar@nku.edu.tr D https://orcid.org/00000002-4683-820X

Atıf/Citation: Cemal POLAT, Çetin YAĞCILAR. The Effects Of Feeding Frequencies On The Growth Performance And Life Rate In Electric Yellow Fish Fry (Labidochromis caeruleus). Tekirdă̆ Ziraat Fakültesi Dergisi, 18 (3), 578-585.

(CBu çalışma Tekirdağ Namık Kemal Üniversitesi tarafından Creative Commons Lisansı (https://creativecommons.org/licenses/by-nc/4.0/) kapsamında yayınlanmıştır. Tekirdağ 2021
} 


\section{$\ddot{\mathbf{O} z}$}

Süs balığı yetiştiriciliği Dünya’ da önemli bir endüstri haline gelmiştir. Süs balıkları, renkleri, şekilleri ve davranış özellikleri nedeniyle yaşayan mücevherler olarak adlandırılmaktadır. Modern süs balığı üretimi, besin yönünden dengeli, uygun maliyetli ve sürdürülebilir bir besleme sürecine gereksinim duymaktadır. Su ürünleri yetiştiriciliğinde işletme giderleri arasında yem maliyeti toplam diğer giderler arasında \% 40 ila \% 60 oranında değişen bir orana sahiptirBu çalışmada, sarı prenses ciklet yavrularında (Labidochromis caeruleus), öğün sayısının büyüme performansı ve yaşama oranı üzerindeki etkilerinin araştırılması amaçlanmıştır. 60 adet sarı prenses çiklet yavrusu Tekirdağ Namık Kemal Üniversitesi Teknik Bilimler Meslek Yüksekokulu Su Ürünleri Laboratuvarında kurulan 12 adet 33*35*40 cm büyüklüğündeki akvaryumlara stoklanmıştır. Çalışma balıklara 4 farklı öğün sayısı uygulanarak, vücut ağırlığının \% 5' i kadar günde 1 öğün, 3 öğün, 5 öğün ve gün aşırı 1 öğün olmak üzere 3 tekerrürlü olarak gerçekleştirilmiştir. Çalışma boyunca 30 günde bir ağırlık tartımları ve boy ölçümleri yapılmış olup elde edilen veriler araştırma sonunda değerlendirilerek büyümenin ögün sayısına etkisi araştırılmıştır. Deneme sonunda vücut ağırlıkları sırasıyla $3.696 \pm 1.517 \mathrm{~g}, 4.757 \pm 1.898 \mathrm{~g}, 3.786 \pm 1.539 \mathrm{~g}$ ve $3.380 \pm 1.318 \mathrm{~g}$, toplam boyları ise $5.726 \pm 0.675 \mathrm{~cm}, 6.300 \pm 0.530 \mathrm{~cm}, 5.640 \pm 0.776 \mathrm{~cm}$ ve $4.562 \pm 1.952 \mathrm{~cm}$ olarak ölçülmüştür. Çalışmada uygulanan öğün sayıları arasında ortalama canlı ağırlık artışı ve spesifik büyüme oranı açısından istatistiksel bir fark bulunmamıştır. Ancak balıkların boy uzunluklarında elde edilen sonuçlara göre gün aşırı 1 öğün beslenme ile diğer öğün sayıları arasında istatiksel olarak fark elde edilmiştir. Sonuç olarak balık sağlı̆̆1 ve yem maliyeti dikkate alındığında balıkların günlük besleme sıklığının 3 defa yapılması yeterli olarak görülmüştür.

Anahtar Kelimeler: Labidochromis caeruleus, Öğün sayısı, Büyüme performansı, Yaşama oranı, Canlı ağırlık artış1 


\section{Introduction}

Ornamental fish farming has become an important industry in the world. Ornamental fish are called living gems because of their colour, shape, and behaviour. The worldwide trade of ornamental fish, wholesale, retail sales of fresh and saltwater fish, and all materials used in the industry, is estimated at approximately US \$15 - 30 billion per year. Asian countries, which hold approximately 55\% of the global market supply, also make a significant contribution to their national economies through this sector (Globefish, 2021).

Countries with tropical climates, which are not economically powerful, are among the countries that generate a great source of income through marketing aquarium fish to foreign countries by catching or breeding. Indonesia, India, and Singapore are the leading countries with the most employees in this sector. It is estimated that around one million people earn their living in the aquarium sector in developing world countries (Hekimoğlu, 2006).

The Cichlidae family constitutes the largest family of ornamental fish. Altınköprü (1981) reported that the Cichlidae family had 100 genera and more than 1.000 species also, Riehl and Baensch (1985), 160 genera, and 900 species. Its natural habitats are the northwestern parts of Africa and the southern regions, Cuba, Tahiti and Argentina, South India and Sri Lanka (Ceylon) in Asia, and the regions extending from South Texas to Central America in the south and central America. There are 700 species in Africa, more than 200 species in America, and 3 species in Asia (Riehl and Baensch, 1985). The natural habitat of electric yellow cichlid fish is Lake Malawi, the 9th largest lake in the world and the last of the valley lakes, located in Africa. The oxygen level is very low after about 200 metres (Grzimek, 1972). Sir John Kirk conducted the first study carried out on Lake Malawi in the 19th century, and later Albert Gunther and Boulenger identified many Cichlid species with their studies. Cichlids have a single dorsal fin, the anterior part of the dorsal fin is hard-beamed, and the posterior part is softbeam. Its sidelines are usually in two parts. They are $5-30 \mathrm{~cm}$ in height and can reach a maximum length of $80 \mathrm{~cm}$. In many parts of the world, some species are grown as edible fish to meet the animal protein needs of people (Riehl and Baensch, 1985).

Electric yellow cichlids (Labidochromis caeruleus) fish are known as a peaceful species in aquariums. Adults can reach 10-12 cm in length. Electric Yellow Cichlids can live in the same aquarium with all cichlid species. These fish like to live on shallow cliffs. Therefore, there should be objects in the aquariums where the fish can hide. Since electric yellow cichlids damage the plants in their aquariums, the plants are not desired in the environment (Alpbaz, 2000).Labidochromis caeruleus, which is the subject of the research, is known as electric yellow cichlid among aquarists, as Blue Streak Hap (Kullander, 1997) abroad, and as electric yellow cichlid on various websites.

Since the species belonging to the cichlid family live in various habitats, they are fully compatible with environmental conditions and ecological characteristics and compared to other fish families. A water temperature between $22-28^{\circ} \mathrm{C}$ is the most suitable value for their life. They generally prefer live baits (Tubifex, Enchytraeus albidus, Daphnia sp., Cyclops sp., Artemia salina nauplii) (Altınköprü., 1981; Riehl and Baensch., 1985). At the same time, in closed system cultivation, it is necessary to use carotenoid-added feeds, which act as antioxidants in biological systems and as precursors of vitamin A in the endocrine and immune system, in order for the fish to have healthy and vibrant colors (Şamlı et al., 2005).

Approximate operating costs in animal production $70 \%$ of feed costs (Şamlı and Onarbay, 2011). Similarly, total feed in fish farms has a high value compared to other operating costs. This allows businesses to keep feed costs as low as possible and reduce the cost of fish. Feeding frequency plays an important role in growth, survival rate, water quality and treatment, especially in fish (Davies et al., 2006). Various researches have been made according to different fish species and different numbers in their research. Mabroke et al. (2021), tilapia fish fry 1, 2, 3, 4 and 5 times a day with 32\% protein feed, Öz et al. (2017) Cyprinus carpio fry, 2, 3 and 5 times a day with $47.5 \%$ protein feed for 60 days; Kasiri et al (2011), Pterophyllum skalare fry with a weight of 0.87 grams per day 1, 2, 4 and every other day; Davies et al. (2006) in Heterobranchus longifilis fry with feed with $40 \%$ protein once a day, once every other day and twice a day and Sultana et al. (2001) in their studies; Cyprinus carpio fry ranging from $5.61 \mathrm{~g}$ to $7.81 \mathrm{~g}$ with feed with $33 \%$ protein, which they feed at a rate of $5 \%$ of their daily body weight, 2, 3, 4,5 and 6 times a day. 


\section{Materials and Methods}

\subsection{Trial plan and type of fish}

The research was carried out in the Vocational School of Technical Sciences aquaculture laboratory of Tekirdağ Namık Kemal University (Figure 1).

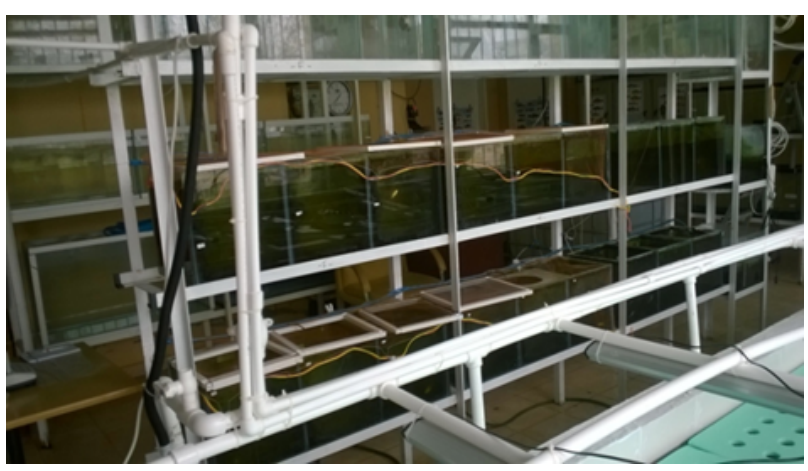

Figure 1. Trial Plan

The experimental fish were obtained from a producer engaged in commercial aquarium fish farming in Istanbul. 60 Electric yellow cichlid fries (Labidochromis caeruleus) the healthiness of which were ensured, were used in the study. Before starting our experiment, the fish were subjected to a 7 day adaptation and 10 day feed acclimatisation process. In the research to be conducted with baby electric yellow cichlid fish, 12 aquariums made of glass with dimensions of $100 * 33 * 34 \mathrm{~cm}$ were used. Aquariums were provided with both biological filtration and aeration using central filtration. In this research, rested chlorine-free tap water was used in aquariums with a water height of $30 \mathrm{~cm}$. During the research, the temperature of the water was kept constant at $24 \pm 2^{\circ} \mathrm{C}$ through thermostat heaters.

Electric yellow fish are timid species. They want environments where they can be kept in the aquarium. This needs to be placed in the aquarium with materials that can be hidden such as rocks. For this purpose, one PVC pipe is placed in aquariums. Bottom material such as sand and gravel is not placed at the bottom of the aquarium. Thus, bottom cleaning could be carried out more quickly and without stressing the fish. In order to remove the chlorine used by the municipality to disinfect the water for public health, the aquariums were rested for 24 hours after they were filled. The experiment was conducted with 3 replications, using 4 different number of meals: 1 meal a day, 3 meals a day, 5 meals a day, and 1 meal every other day. Feeding of the fish took place at 9 am for 1 meal per day; at $9 \mathrm{am}, 1 \mathrm{pm}$, and $5 \mathrm{pm}$ for 3 meals per day; at $9 \mathrm{am}, 11 \mathrm{am}, 1 \mathrm{pm}, 3 \mathrm{pm}$, and $5 \mathrm{pm}$ for 5 meals per day; and at 9 am for 1 meal per day.

Among the water quality values measured during the experiment, salinity was recorded as $289.6 \mathrm{ppm}$, TDS $481.9 \mathrm{ppm}$, conductivity $628.3 \mu \mathrm{S}$, aquarium temperature $26.3^{\circ} \mathrm{C}$, ambient temperature $27.4^{\circ} \mathrm{C}$, ambient humidity 69.3, pH 8.0 and Oxygen 10.0.

\subsection{Trial feed used}

Commercial Dainichi Veggie Fx brand herbal $1 \mathrm{~mm}$ size sinking feed was used in feeding fish, and the nutritional content of the feed used is given in Table 1 . The fish were fed to $5 \%$ of their live weight. The bottom was cleaned twice a week, equal to one-third of the aquariums, and the water equivalent in temperature to water in the aquariums was added to the aquariums to remove the feed residues and faeces accumulated in the aquariums. The weight measurements of the fish used in the experiment were made every 20 days with an AND brand digital scale with an accuracy of $0.01 \mathrm{~g}$ (Figure 2). Length measurements were made with a plastic ruler. When weighing, the fish were placed in a container (with the tare determined) with water from the aquarium of the given fish, and they were then weighed one by one. On the weighing days, the fish were not fed, and the weighing days were not included in the experiment period. 
Table 1. Nutritional content of the feed used

\begin{tabular}{ccccc}
\hline Crude protein & Crude oil & Crude fiber & Moisture & Ash \\
\hline 39 & 5 & 4 & 9 & 12 \\
\hline
\end{tabular}

In order to evaluate the data obtained at the end of the experiment;

$\mathrm{X}_{0}=$ Average body weight per trial $(\mathrm{g})$

$\mathrm{X}_{1}=$ Average body weight at the end of the trial $(\mathrm{g})$

$\mathrm{Y}_{0}=$ Average height per trial $(\mathrm{cm})$

$\mathrm{Y}_{1}=$ Average height at the end of the trial $(\mathrm{cm})$

$\mathrm{d}=$ Trial period (days)

Average live weight gain $(\mathrm{g})=\mathrm{X}_{1}-\mathrm{X}_{0}$

Average height increase $(\mathrm{cm})=\mathrm{Y}_{1}-\mathrm{Y}_{0}$

Proportional growth rate $($ weight $)(\%)=\left(\mathrm{X}_{1}-\mathrm{X}_{0}\right) / \mathrm{X}_{0} \times 100$

Proportional growth rate (height) $(\%)=\left(\mathrm{Y}_{1}-\mathrm{Y}_{0}\right) / \mathrm{Y}_{0} \times 100$

Daily absolute height increase $(\mathrm{cm})=\left(\mathrm{X}_{1}-\mathrm{X}_{0}\right) / \mathrm{d}$

Daily absolute body weight gain $(\mathrm{g})=\left(\mathrm{Y}_{1}-\mathrm{Y}_{0}\right) / \mathrm{d}$

Specific growth rate $\left(\%\right.$ day $\left.^{-1}\right)=\left(\left(\ln X_{1}-\ln X_{0}\right) / d\right) \times 100($ Çelikkale, 1994) formulas are used.

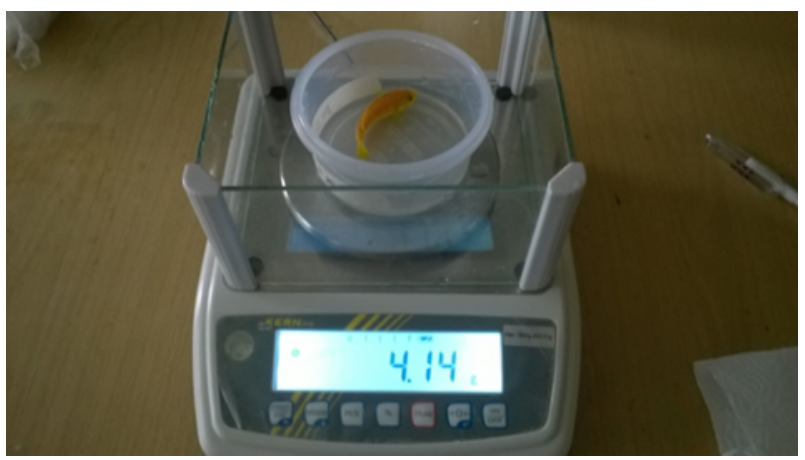

Figure 2. Individual weight measurement

\subsection{Statistical analysis}

IBM SPSS Statistics 25.0 package program was used for the statistical analysis of the data obtained from the analyzes, and analysis of variance (One-Way Anova) was applied in the multi-group comparisons and the differences between the averages were determined by the Tukey Test $(p<0.05)$.

\section{Results and Discussion}

\subsection{Body weight and height increase}

At the end of the research, the body weights obtained with the number of meals 1,3,5 and 1 every other day applied to fish fed with $5 \%$ of their body weight were $3.696 \pm 1.517 \mathrm{~g}, 4.757 \pm 1.898 \mathrm{~g}, 3.786 \pm 1.539 \mathrm{~g}$ and $3.380 \pm 1.318 \mathrm{~g}$, respectively (Table 2). Likewise, at the end of the trial, the total heights obtained with the number of meals 1, 3, 5 and 1 every other day were measured as $5.726 \pm 0.675 \mathrm{~cm}, 6.300 \pm 0.530 \mathrm{~cm}, 5.640 \pm 0.776 \mathrm{~cm}$ and $4.562 \pm 1.952 \mathrm{~cm}$, respectively (Table 3). The daily absolute height increase $(\mathrm{cm})$, daily absolute body weight increase $(\mathrm{g})$ and the specific growth rate $\left(\%\right.$ day $\left.^{-1}\right)$ are shown in Table 4 is also given.

In our study, although there was a numerical difference in weight measurements in yellow princess fish fed as 1,3, 5 meals a day and 1 meal every other day, there was no statistically significant difference $(p<0.05)$. However, as seen in Table 4, the specific growth rate is high in fish fed 3 meals a day, followed by fish fed 5 and 1 meals a day, respectively, and finally fish fed 1 meal every other day. When we look at the height increase rates of the fish in Table 3 , it was observed that the fish in the groups fed 1,3 and 5 meals a day were statistically different from the fish fed with 1 meal every other day. 
Table 2. Average live weight of fish at the beginning and end of trial, average weight increase and proportional growth rate

\begin{tabular}{cllll}
\hline Groups & $\begin{array}{l}\mathrm{X}_{0}(\mathrm{~g}) \\
\overline{\boldsymbol{x}_{0}} \pm \boldsymbol{S} \overline{\boldsymbol{x}}\end{array}$ & $\begin{array}{l}\mathrm{X}_{1}(\mathrm{~g}) \\
\overline{\boldsymbol{x}_{1}} \pm \boldsymbol{S} \overline{\boldsymbol{x}}\end{array}$ & $\begin{array}{l}\text { Average live } \\
\text { weight gain }(\mathrm{g})\end{array}$ & $\begin{array}{l}\text { Proportional } \\
\text { growth rate }(\%)\end{array}$ \\
\hline 1 meal a day & $1.516 \pm 0.486$ & $3.696 \pm 1.517^{\mathrm{a}}$ & 2.180 & 143.799 \\
$\begin{array}{c}3 \text { meal a day } \\
5 \text { meal a day }\end{array}$ & $1.536 \pm 0.462$ & $4.757 \pm 1.898^{\mathrm{a}}$ & 3.221 & 209.700 \\
$\begin{array}{c}1 \text { meal every } \\
\text { other day }\end{array}$ & $1.517 \pm \pm 0.518$ & $3.786 \pm 1.539^{\mathrm{a}}$ & 2.310 & 156.504 \\
\hline
\end{tabular}

Means within rows with different superscripts differ from each other $(\mathrm{p}<0.05)$

Table 3. Average length of fish at the beginning and end of trial, average height increase and proportional growth rate

\begin{tabular}{lllll}
\hline Groups & $\begin{array}{l}\mathrm{Y}_{0}(\mathrm{~cm}) \\
\mathrm{y}_{0} \pm \boldsymbol{S} \overline{\boldsymbol{x}}\end{array}$ & $\begin{array}{l}\mathrm{Y}_{1}(\mathrm{~cm}) \\
\mathrm{y}_{1} \pm \boldsymbol{S} \overline{\boldsymbol{x}}\end{array}$ & $\begin{array}{l}\text { Average height } \\
\text { increase }(\mathrm{cm})\end{array}$ & $\begin{array}{l}\text { Proportional } \\
\text { growth rate }(\%)\end{array}$ \\
\hline 1 meal a day & $4.460 \pm 0.488$ & $5.726 \pm 0.675^{\mathrm{a}}$ & 1.266 & 28.385 \\
3 meal a day & $4.586 \pm 0.394$ & $6.300 \pm 0.530^{\mathrm{a}}$ & 1.714 & 37.374 \\
5 meal a day & $4.500 \pm 0.539$ & $5.640 \pm 0.776^{\mathrm{a}}$ & 1.140 & 25.333 \\
1 meal every other day & $4.520 \pm 0.534$ & $4.562 \pm 1.952^{\mathrm{b}}$ & 0.042 & 0.929 \\
\hline
\end{tabular}

Means within rows with different superscripts differ from each other $(\mathrm{p}<0.05)$

Table 4. Daily absolute height, body weight gain and specific growth rates obtained at the end of the trial

\begin{tabular}{cccc}
\hline Groups & $\begin{array}{c}\text { Daily absolute height } \\
\text { increase }(\mathrm{cm})\end{array}$ & $\begin{array}{c}\text { Daily absolute body } \\
\text { weight gain }(\mathrm{g})\end{array}$ & $\begin{array}{c}\text { Specific growth } \\
\text { rate }\left(\% \text { day }^{-1}\right)\end{array}$ \\
\hline 1 meal a day & 0.021 & 0.036 & 1.485 \\
3 meal a day & 0.028 & 0.053 & 1.883 \\
5 meal a day & 0.019 & 0.038 & 1.570 \\
$\begin{array}{c}\text { 1 meal every } \\
\text { other day }\end{array}$ & 0.0007 & 0.031 & 1.335 \\
\hline
\end{tabular}

The results obtained are evaluated with the studies in the literature; Mabroke et al. (2021), a total of 300 tilapia fry with an average of $7.9 \mathrm{~g} \pm 0.03$ fed with a feed with $32 \%$ protein per day for 60 days 1,2, 3, 4 and 5 assumed. No statistical difference $(p>0.05)$ was found between the groups determined in the study in terms of growth parameters. In a different studies, Öz et al. (2017) fed $18 \%$ of koi (Cyprinus carpio) fry with an average weight of $0.015 \pm 0.001 \mathrm{~g}$ with commercial aquarium fish food for 60 days 2,3 and 5 times a day. As a result of the statistical analysis, they reported that the difference between the groups was insignificant in terms of average live weight gain, feed utilization rates, specific growth rates and survival rates in carp juveniles. Although there was no statistical difference $(p>0.05)$ in the data obtained at the end of the experiment, the growth values increased as the frequency of feeding increased. When the data obtained at the end of the trial are examined, it is similar to our study in terms of body weight gain.

As a different result according to the data obtained in our study; Kasiri et al. (2011), four groups of angel fish juveniles $(0.87 \pm 0.01 \mathrm{~g} ; 3.98 \pm 0.08 \mathrm{~mm})$ were fed either four meals per day (F1), two meals per day (F2), one meal per day (F3) and every other day (F4) for 90 days. Final live weight and specific growth rate (SGR) values of group F1 and F2 were significantly higher than those of the other groups $(\mathrm{P}<0.05)$. Also, Davies et al. $(2006)$ Heterobranchus longiphilis fry were fed once a day, twice a day and once every two days with the feed with a crude protein content of $40 \%$ for 56 days. Sultana et al. (2001) Cyprinus carpio juveniles fed 2, 3, 4, 5 and 6 times 
The Effects of Feeding Frequencies on The Growth Performance and Life Rate In Electric Yellow Fish Fry (Labidochromis caeruleus). a day for 45 days with a feed with $33 \%$ crude protein. At the end of the feeding trial, significantly different and higher $(\mathrm{p}<0.05)$ growth response was observed in treatment $\mathrm{C}$ having a feeding frequencies of 4 times a day. Although there was no statistical difference in terms of weight gain in yellow princess fish, a statistical difference was obtained as an increase in length growth in the frequency of feeding in fish.

\subsection{Survival rate}

Kasiri et al (2011), There was no significant difference $(\mathrm{P}>0.05)$ in survival rate among the treatments. Davies et al (2006), survival was not significantly different among treatments except for fingerlings fed once every other day. Considering the mortality rates in fish with different meal numbers tested in our study, there was no death in the groups fed 1, 3 and 5 meals a day. However, death was observed in the group that received one meal every other day. Considering the distribution of the number of deaths in this group, a total of 7 fish deaths were detected, 2 in the second measurement, 4 in the third measurement and 1 in the last measurement (Figure 3).

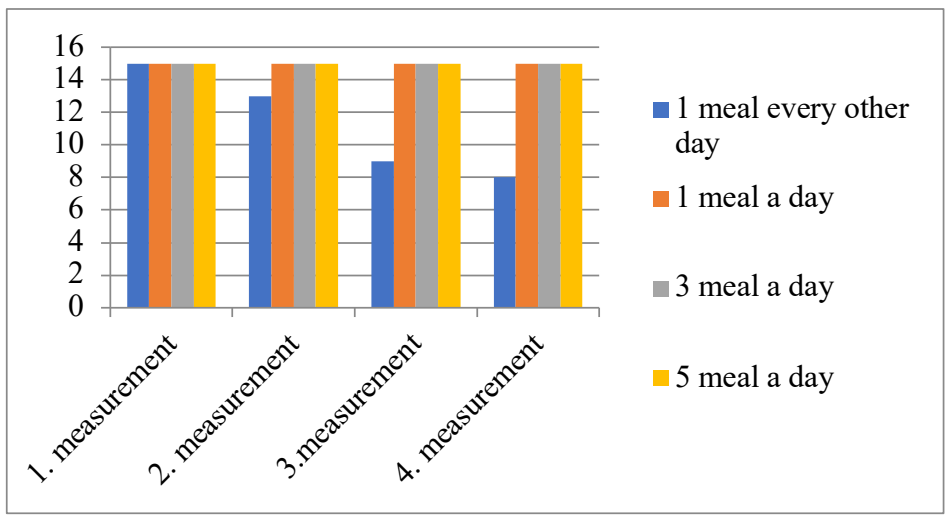

Figure 2. Survival rate

\section{Conclusions}

The frequency of feeding varies according to the workforce, size, production system of an enterprise, the type and size of the fish being grown. Feeding frequency has a direct effect on the growth and feed conversion rate of fish. However, determining the density of feeding in ideal conditions also reduces the cost of feed. As a result of our research; no statistical difference was found between the number of meals administered in the study in terms of average body weight gain and specific growth rate. However, according to the results obtained in the length of the fish, a statistical difference was found between feeding 1 meal every other day and the number of other meals. As a result, considering the fish health and feed cost, 3 times daily feeding frequency of the fish was considered sufficient. 


\section{References}

Alpbaz, A., (2000). Akvaryum Balıkları Ansiklopedisi Mas matbaası, İzmir

Altınköprü, T. (1981). Akvaryum Balıklarının Üretilmesi. Altınköprü yayınları. Nur Ofset İstanbul.

Çelikkale, M. S. (1994). İç su balıkları yetiştiriciliği. K.T.Ü. Sür. Den. Bil. Fak. Cilt I, K.T.Ü. Basmevi, Trabzon, 419s.

Davies, O. A., Inko Tariah, M. B. and Amachree, D. (2006). Growth response and survival of Heterobranchus longifilis fingerlings fed at different feeding frequencies. African Journal of Biotechnology Vol. 5 (9), pp. 778-780.

Globefish - Information and Analysis on World Fish Trade (2021). Erişim adresi: http://www.fao.org/in-action/globefish/news-events/detailsnews/en/c/1373555

Grzimek, B. (1972). Animal Life Encyclopedia. Van Nostrand Reinhold company, p. 136, vol:5 New York.

Hekimoğlu, M. (2006). Akvaryum Sektörünün Dünyadaki ve Türkiye'deki Genel Durumu.. Ege Journal of Fisheries and Aquatic Sciences, 23 (2), 237-241. Retrieved from http://www.egejfas.org/tr/pub/issue/5015/67978

Kasiri, M., Farahi, A., Sudagar, M. (2011). Besleme Sıklığının Melek Balığı, Pterophyllum scalare (Perciformes: Cichlidae) Büyüme Performansı ve Yaşama Oranı Üzerindeki Etkileri. Veteriner Araştırma Forumu , 2 (2), 97-102.

Kullander, Sven O. (1997). The Cichlids of Surinam: Teleostei, Labroidei, Brill Academic Publishers, pp.256, ISBN: 13978-9004090774

Mabroke, R. S., Zidan A. E. F.A, Tahoun A., Mola H. R. A., Abo-State H., Suloma A. (2021). Feeding frequency affect feed utilization of tilapia under biofloc system condition during nursery phase. Aquaculture Reports 19 (2021) 100625. https://doi.org/10.1016/j.aqrep.2021.100625

Öz, M, Aral, O, Şahin, D, Erik, H. (2017). Farklı Besleme Sıklıklarının Koi Carp (Cyprinus Carpio) Fry 'nın Yetiştirilmesi Üzerine Etkileri. Su Bilimleri ve Mühendisliği, 32 (4), 208-213. DOI: 10.18864 / TJAS201719

Riehl, R., Baensch, H.A. (1985). Aquarium atlas, J.Fac.Mar.Sci. technology.Tokai university Tokaidai Kiyo, no:24 pp.133-140.

Sultana, S.M., Das, M., Chacraborti, S.C. (2001). Effect of feeding frequency on the growth of common carp (Cyprinus carpio L.) fry. Bangladesh Journal of Fisheries Research, 5(2), 149-154

Şamlı, H , Onarbay, O. (2011). Farklı Depolama Şartlarının Bazı Protein Kaynaklı Yem Hammaddelerinin Özellikleri Üzerindeki Etkilerinin Belirlenmesi . Tekirdağ Ziraat Fakültesi Dergisi , 8 (3) , 40-45 . Retrieved from https://dergipark.org.tr/tr/pub/jotaf/issue/19041/201391

Şamlı, H.E., Şenköylü, N., Akyürek, H., Ağma, A. (2005). Doğal Pigmentlerin Yaşlı Tavuklarda Yumurta Sarısına Etkileri. Tekirdağ Ziraat Fakültesi Dergisi , 2 (3) , 281-286. Retrieved from https://dergipark.org.tr/tr/pub/jotaf/issue/19059/201595 